\title{
The Determinant Factors of Employees' Behavioral Intention in Green Building Restaurants- Integration TRA and TAM
}

\author{
Li-Min Chuang ${ }^{1}$, Pi-Ching Chen ${ }^{2}$, Yen-Yu Chen ${ }^{1,3, *}$ \\ ${ }^{1}$ Graduate School of Business and Operations Management, Chang Jung Christian University, Tainan City 71101, Taiwan
${ }^{2}$ Department of International Business, Chang Jung Christian University, Chang Jung Christian University, Tainan City 71101 , Taiwan
${ }^{3}$ Department of Hospitality Management, Tajen University, Pingtung County 90741, Taiwan
}

Copyright $\bigcirc 2016$ by authors, all rights reserved. Authors agree that this article remains permanently open access under the terms of the Creative Commons Attribution License 4.0 International License

\begin{abstract}
This study integrated with technology acceptance model (TAM) and theory of reasoned action (TRA) to construct a behavior model of green building restaurants. On the basis of TAM analysis, four constructs were identified: perceived usefulness, perceived ease of use, attitude and intention. Three constructs were identified from TRA: motivation to comply, subjective norm and intention. The results shown: first, perceived usefulness, and perceived ease of use green building restaurants in Taiwan has an indirect effect on intention through attitude; second, motivation to comply has indirect effect passes through both subjective norm and attitude sequentially, with subjective norm affecting attitude. Finally, motivation to comply has an indirect effect on intention through subjective norm.
\end{abstract}

Keywords Technology Acceptance Model (TAM), Theory of Reasoned Action (TRA), Green Building Restaurant

\section{Introduction}

Going green" is a key issue in the convention/meeting industry today $[15,66]$. The context of pro-environmental decisions/behaviors has been repeatedly asserted by researchers $[21,46,58,73]$.

Urban excessive exploitation and industrial development rapidly results in heat island and greenhouse effect that the human living environment is facing unprecedented difficulties. However, how to improve the excessive use of resources, reduce pollution and environmental damage create a comfortable and safe living environment could become a tremendous challenge for every country. Many advanced countries have proposed the concept of Green Building to alleviate the deterioration of ecological environment, the greenhouse effect and global warming phenomenon. There is no exception for Taiwan. Environmental and climate change issues have obvious continuously expanding awareness of sustainable environmental development [55, 67]. Taiwan's government approved the implementation of "eco-city program to promote green building," in 2008 January 11. The main purpose is to expand the level of green buildings, ecological communities, and ecological cities in order to achieve the goal of sustainable homeland. However, the importance of green building is not just emphasize the architectural design symbiotic with the global environment, as well as improved building power, water fees and excessive use of resources and other issues. Energy conservation is the most effective way to use resources, reduce pollution and make the building safe, healthy living environment space, to achieve a way of building architecture and environment communion. The environment is being destroyed daily by human life and restaurants are a part of the problem [20]. To solve this problem, some restaurants are now promoting and implementing sustainability initiatives [20]. In this study, "Taiwanese restaurants" as the object of study, it investigated the restaurants employees' intention of use of green building. Eco-friendly restaurants through operation, construction, and design attack environment depletion. Green building design is tightly focused on efficiency, renewable materials, and waste reduction. The consequence of this attitude is that an increasing number of organizations are admitting their environmental responsibility [16]. The pro-environmental issues getting more attraction and attention within hospitality research in recent years.

Restaurant owners adopt green practices to their properties with the purpose of creating a distinctive image that can differentiate them from their competitors. Therefore, restaurateurs strive to get this competitive advantage by introducing green practices into their restaurants. Consequently, restaurants managers have implemented corporate programs aimed at saving natural resources such as water, decreasing energy consumption, reducing water 
and air pollution, solid waste and using resources efficiently $[14,36]$ to keep at the minimum the expenditure and to maximize profit, as it has been accepted that these activities result in cost savings [14].

This initiative consists of organizing meetings and events taking into account environmental issues guaranteeing a responsible consumption of resources and materials. Several restaurants have incorporated eco-friendly business practices into their implementation with environmental concerns and awareness [38]. This led a great change in employees' behaviors and attitudes toward eco-friendly business establishments $[25,75]$.

This study integrates both TRA and TAM to predict the intention of applying green restaurant. TAM discusses the use and promotion of a technology from the perspective of users [40]. It has been widely used in many studies, except for those related to the construction industry. TAM mainly explores the influences of external factors on internal factors of users, such as their beliefs, attitudes and intentions toward using a technology, and the influences of these internal factors on their use of the technology. The empirical study $[70,71]$ found that, after users actually used or learned about the use of a new technology, their perceived usefulness of the technology had a direct influence on the level of their use of this technology. In addition, this method often leads to material losses and waste of materials [43]. To reduce the pollutions and inconveniences caused by traditional cement. The theory of reasoned action (TRA) [2], widely explain the development of employees' intention to applying green materials in restaurants. Such greening efforts by eco-friendly restaurants not only contribute to fulfill employees' needs in the workplace, but lower operational costs by reducing the significant extent of solid waste and energy/water consumption [53]. Theory of Reasoned Action (TRA) [2] predicts employees' green applying intention. "Sustainable consumption refers to minimize the use of natural resources, of toxic materials and emissions of waste and pollutants over the life- cycle, so as not to jeopardize the needs of future generations" $[23,30,44]$.

TRA predicted individuals' decisions and behaviors when applied in any activity or situation [34]. Because of its precision in predicting human behaviors and effectiveness in explaining processes in decision-making, Environmental protection continually attracts public attention $[17,31,33$, 36]. Individuals are becoming more and more aware of the environmental damage caused by numerous business practices [53]. That is the reason of this study integrating TRA and TAM to predict the employees' behavioral intention of applying green materials in restaurants.

\section{Materials and Methods}

\subsection{Literature Review}

This study applied theory of reasoned action and technology acceptance model into investigate restaurants employees' attitudes, subjective norms, and intention toward green building restaurants. Numerous factors contribute to environmental degradation, such as carbon dioxide emissions, unreprocessable wastes, and unrecyclable end products $[44,49]$. To protect the environment, governments and environmental protection groups worldwide have suggested implementing green and sustainable manufacturing processes, and indicating the environmental friendliness of these processes on product labels. Numerous studies have suggested evaluating the influence of behavioral approaches on raising awareness of environmental issues $[8,45,50,51]$. Some researchers focused on the behavior of individuals and citizens, whereas few studies have examined manufacturers' perspectives and attitudes toward green behavior [13, 27, 35].

These researchers and practitioners have indicated pro-social/pro-environmental behavior indicates that attitude toward the behavior, social norm, and anticipated emotions can be related to the TRA $[32,54,58]$.

\subsubsection{Green building Restaurants}

Lorenzini [52] defined a green building restaurant as a restaurant with "new or renovated structures designed, constructed, and operated, in an environmentally-friendly and energy-efficient manner". According to Kubba (47), green buildings are designed and provided for healthier, more comfortable and productive indoor environments with maximizing the efficient usage of resources like energy, water, and recycled materials. The American Society of Testing and Material [9] proclaims that green buildings provide the particular building function requirements while minimizing disruption and meliorating the performance of local, regional and global ecosystems during and after its construction and particular service life. According US Green Building Council (USGBC) indicates LEED (Leadership in Energy and Environmental Design) [63] Green Building Rating System should include six major criteria: building sustainability; water efficiency; energy and atmosphere; raw materials and resources; indoor environmental quality measures [74]; and innovative design.

\subsubsection{Theory of Reasoned Action (TRA)}

Theory of reasoned action was first proposed by Fishbein \& Ajzen in 1975 [26]. The theory of reasoned action [3,6, $26,12]$ is practically well researched intention models that have proven successful in predicting and explaining behavior across a wide variety of domains [72].The theoretical foundation is resulted from social psychology, primarily for predicting personal attitude (Attitude), and behavioral intentions (Behavior Intention) [7,8,10,65]. Ajzen \& Fishbein [4] indicated that "TRA assumes that individuals are usually rational and will consider the implications of their actions prior to deciding whether to perform a given behavior". TRA made up of a person's behavioral, normative, and determine his attitudes, subjective norm, and behavioral intention [60].

Intention defines that individual's attitude engage in a particular behavior.

Subjective norm is a set of normative beliefs and 
perception of social pressures in particular behavior [26]. Attitude refers to the person's own performance of the behavior [26].

Motivation to comply is their compliance with the wishes of their, family, friends and colleagues [72].

\subsubsection{Technology Acceptance Model (TAM)}

The technology acceptance model (TAM) originally developed by Davis [22]. The model promotes users' willing to apply new technology. The potential users will feel like new technology easier to use and obtain benefits from it. Therefore, the more positive of perceived usefulness and perceived ease of use it is, the higher of attitude.

TAM provides a valuable insight into users' acceptance and use of technology. Perceived usefulness (PU) is defined the user's "subjective probability that using a particular technology will enhance his or her job performance and adopting organization's well-being." [26]. Users will hold a positive attitude toward new technology, and this includes doing the job with less time and more efficiency and accuracy.

Perceived ease of use (PEU) is "the degree to which the user expects the particular system to be effortless and more beneficial" [26]. Therefore, Individuals required less manpower and time consuming toward new technology, more likely to be accepted by the user [26]. The Poverty of Economic Explanations of Consumption and an Action Theory Alternative, Managerial and Decision Economics, 21: 95-109.

As such, it is possible that technology with a high level of PU is more likely to induce positive attitudes [5]. The success of any initiatives to implement technology in an application system depends strongly upon the support and attitudes of users' involved [11]. In other words, users' technology usage responses will be affected by their positive or negative attitudes in a technology setting environment [62]. No matter how sophisticated technology is, technology implementation depends on users having a positive attitude toward it [41]. Indeed, Researches stressed that there is a need to assess users' attitudes as these can influence their acceptance of technology use in the future $[57,61,68]$.

\subsection{Hypotheses Development}

This leads to two hypotheses:

H1: Perceived usefulness of green buildings will be positively related to employees' attitude (see figure 1).

$\mathrm{H} 2$ : Perceived ease of use of green building will be positively related to employees' attitude (see figure 1).

Researchers demonstrated behavior intention (BI) leads to actual use of technologies used as the dependent variable in this study [18, 28, 39]. Hu, et al. [39] also indicated that the existence of a strong link between intention and actual behavior. Hsu et al. [37] claimed the technology users' intention is significant influenced by their attitude. In this study, intention is effects by subjective normative, especially the degree of peer pressure one experiences. Bagozzi et al. [12] determined the impact of attitudes and subjective norms on intentions to be reduced after past behavior is introduced. The present study proposes hypotheses:

H5: Employees' attitude of green buildings will be positively related to employees' behavioral intention (see figure 1).

H6: Perception of subjective norm will be positively related to employees' behavioral intention (see figure 1).

Person's subjective norm is weighted by his or her motivations to comply with those referents approve or disapprove of performing the behavior [56]. A person who believes that certain referents will hold a positive subjective norm if he or she perform a behavior and is motivated to meet their expectations [56]. In accordance with prior research, the following hypothesis is proposed:

H3: Perception of motivations to comply will be positively related to employees' subjective norm (see figure 1).

According to Kuo et al. [48] analyzed that results showed that subjective norm positively affects the community residents' attitude to participate in the transformation of urban and rural landscape movement. Based on the findings listed above, the following hypothesis is proposed:

H4: Perception of subjective norm will be positively related to employees' attitude of green buildings (see figure 1).

\subsection{Sample Method}

Data were collected from northern, middle, and southern Taiwanese restaurants. A total of 430 employees from Taiwan participated in this survey. The questionnaires were filled out with anonymity and confidential. The questionnaires were distributed and collected once a week. A total of 365 were returned and fully completed. A return rate is approximately $85 \%$. This study aims to investigate perceived usefulness of green buildings, perceived ease of use with green buildings, attitude of green buildings, motivation to comply, subjective norm, and applying intention of green buildings. Next, the study proposed demographic variables to understand a different view for cognitive perceived usefulness of green buildings, perceived ease of use green buildings, attitude of green buildings, motivation to comply, subjective norm, and applying intention of green buildings.

\subsection{Questionnaire Design}

The survey scale was initially used to develop in English, which was subsequently translated into Chinese. The English and Chinese versions were employing the back-translation technique.

The questionnaire contained six constructs for the study. 
All the variables were analyzed with pilot -test to ensure all of them had reliability exceeding value 0.7 . Items with lower reliability were eliminated.

\subsubsection{Perceived Usefulness of Green Buildings}

The study adapted from Davis [22], Venkatesh and Davis [64] relevant scales to measure perceived usefulness of green buildings. The construct of perceived usefulness of green buildings took reference from Davis [22] and Venkatesh and Davis [22] and is redefined as follows: "organization employees believe that participate in green building activities will enhance the corporate image, create a comfortable working environment, relieve environmental protection or to enhance the business performance". A Likert five-point scale ranging from 1 = "strongly disagree" to $5=$ "strongly agree" was applied in the questionnaires.

\subsubsection{Perceived Ease of Use Green Buildings}

The study adapted from Davis [22], Venkatesh and Davis [64] relevant scales to measure perceived ease of use of green buildings. The construct of perceived ease of use of green buildings took reference from Davis [22] and Venkatesh and Davis [64] and is redefined as follows: "organization employees expect the degree of ease of use for participation in green building activity". A Likert five-point scale ranging from $1=$ "strongly disagree" to $5=$ "strongly agree" was applied in the questionnaires.

\subsubsection{Attitude of Green Buildings}

The study adapted from $[1,3,22,26,48]$ relevant scales to measure perceived attitude of green buildings. The construct of attitude of green buildings took reference from Kuo [48] and is redefined as follows: "Organization employees hold a positive or negative evaluation experience to participate in green building activities". A Likert five-point scale ranging from $1=$ "strongly disagree" to $5=$ "strongly agree" was applied in the questionnaires.

\subsubsection{Motivation to Comply of Green Buildings}

The study adapted from [12, 26] relevant scales to measure motivation to comply of green buildings. The construct of motivation to comply of green buildings took reference from Bagozzi et al., [26] and is redefined as follows: "expectations of organization employees with those referents approve or disapprove for green building restaurants and individuals agree or disagree with the degree of compliance". A Likert five-point scale ranging from $1=$ "strongly disagree" to $5=$ "strongly agree" was applied in the questionnaires.

\subsubsection{Subjective Norm of Green Buildings}

The study adapted from $[1,3,26,48]$ relevant scales to measure subjective norm of green buildings. The construct of motivation to subjective norm of green buildings took reference from $[1,3,26,48]$ and is redefined as follows: "Organization employees undertake social pressure in involving green building activities. In addition, the social pressure comes from the colleagues, influential employees, friends and family". A Likert five-point scale ranging from 1 $=$ "strongly disagree" to $5=$ "strongly agree" was applied in the questionnaires.

\subsubsection{Applying Intention of Green Buildings.}

The study adapted from $[1,3,26,48]$ relevant scales to measure applying intention of green buildings. The construct of motivation to applying intention of green buildings took reference from $[1,3,26,48]$ and is redefined as follows: "The willingness of organization employees to participate in the green building activities". A Likert five-point scale ranging from $1=$ "strongly disagree" to $5=$ "strongly agree" was applied in the questionnaires. According to table 1, Cronbach's $\alpha$ of all constructs is larger than 0.7 (See table $1)$.

\section{Results}

\subsection{Reliability and validity analyses}

Structural equation modeling (SEM) was used for model testing. Maximum likelihood was used for all parameters estimation with Amos. First confirmatory factor analysis (CFA) is conducted to evaluate measure the modeled constructs. CFA enables testing of the reliability, and convergent validity of the measurement model.

Convergent validity measures the correlation between two observed variables used to measure the same construct and is expected when the estimated pattern coefficient on the underlying construct factor of the estimated pattern of each coefficient exceeding 0.45 is significant (see figure 2). Items have factor loadings

Table 3 lists the convergent validity result of each latent variable. The standardized factor loadings of each sub-dimension all exceed 0.45 and are significant. Convergent validity thus was achieved for all the study constructs. Discriminate validity was assessed using the approach suggested by Table 3 lists the result of discriminate validity. This study concludes that all measures exhibit construct validity. Based on all of the reliability and validity analysis, the construct scale appears to exhibit satisfactory measurement qualities and is adequate. 


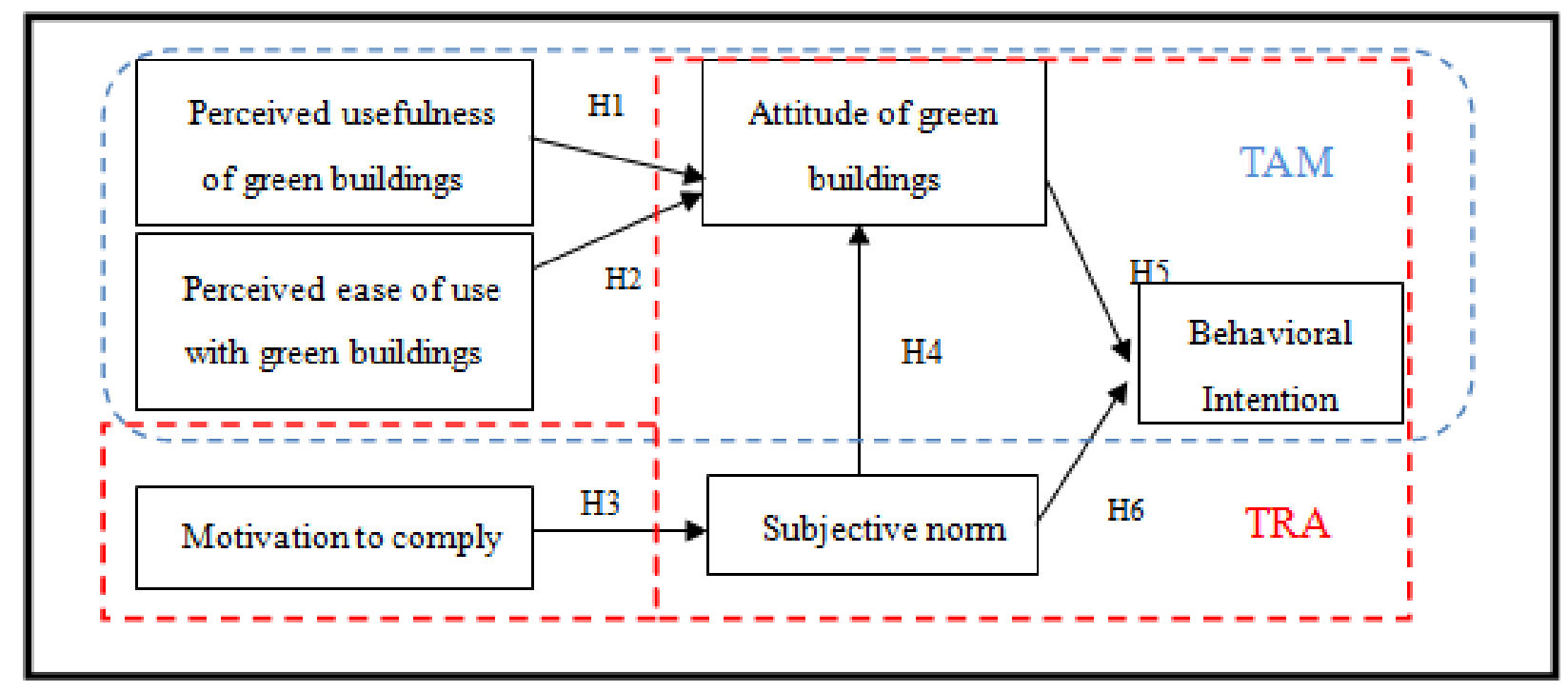

Figure 1. Conceptual model

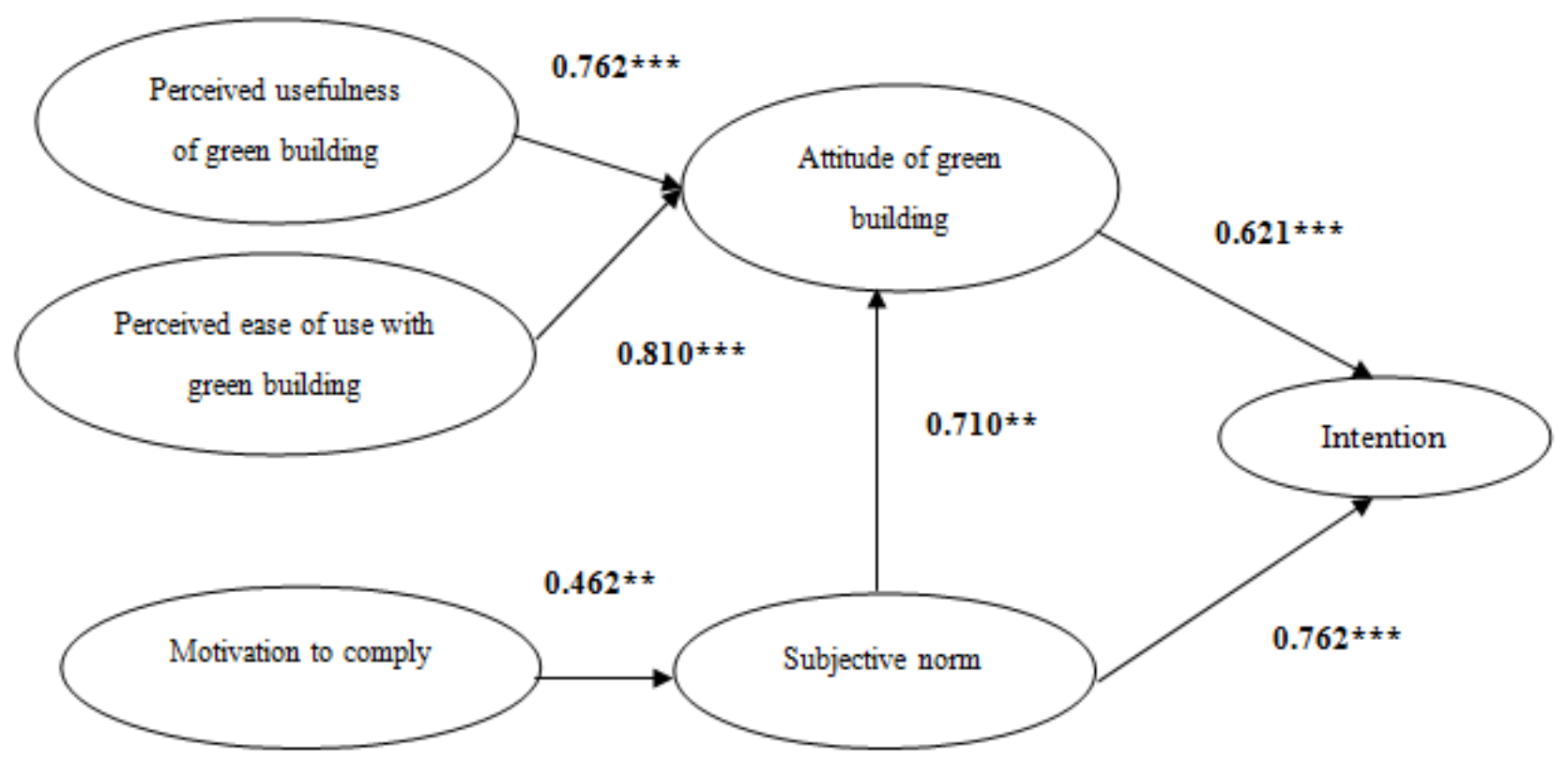

Figure 2. Structural model estimation

Table 1. Reliability Analysis

\begin{tabular}{|c|c|}
\hline \multicolumn{2}{|c|}{ Constructs Reliability Analysis } \\
\hline Construct & Cronbach's $\alpha$ \\
\hline Perceived Usefulness of Green Buildings & 0.739 \\
\hline Perceived Ease of Use Green Buildings & 0.768 \\
\hline Attitude of Green Buildings & 0.756 \\
\hline Subjective Norm of Green Buildings & 0.783 \\
\hline Motivation to Comply of Green Buildings & 0.715 \\
\hline Applying Intention of Green Buildings & 0.726 \\
\hline
\end{tabular}


Table 2. Results from SEM

\begin{tabular}{|c|c|c|c|c|c|}
\hline Relationship & Hypothesis & Loadings & Coefficient & P-Value & $\begin{array}{c}\text { Hypothesis Test } \\
\text { Result }\end{array}$ \\
\hline $\mathrm{PU} \longrightarrow \mathrm{AT}$ & $\mathrm{H} 1$ & 0.764 & 0.762 & $* * *$ & Supported \\
\hline $\mathrm{PEU} \longrightarrow \mathrm{AT}$ & $\mathrm{H} 2$ & 0.826 & 0.810 & $* * *$ & Supported \\
\hline $\mathrm{MC} \longrightarrow \mathrm{SN}$ & $\mathrm{H} 3$ & 0.631 & 0.462 & $* *$ & Supported \\
\hline $\mathrm{SN} \longrightarrow \mathrm{AT}$ & $\mathrm{H} 4$ & 0.702 & 0.710 & $* * *$ & Supported \\
\hline $\mathrm{AT} \longrightarrow \mathrm{AI}$ & $\mathrm{H} 5$ & 0.696 & 0.621 & Supported \\
\hline $\mathrm{SN} \longrightarrow \mathrm{AI}$ & $\mathrm{H} 6$ & 0.732 & 0.762 & S** & Supported \\
\hline
\end{tabular}

$* \mathrm{p}<0.05 ; * * \mathrm{p}<0.01 ; * * * \mathrm{p}<0.001$

Table 3. Discriminate validity coefficient

\begin{tabular}{|c|c|c|c|c|c|c|}
\hline & $\begin{array}{c}\text { Perceived Usefulness } \\
\text { of Green } \\
\text { Buildings(PU) }\end{array}$ & $\begin{array}{c}\text { Perceived Ease of Use } \\
\text { Green Buildings (PEU) }\end{array}$ & $\begin{array}{c}\text { Attitude of Green } \\
\text { Buildings (AT) }\end{array}$ & $\begin{array}{c}\text { Motivation to Comply } \\
\text { of Green } \\
\text { Buildings(MC) }\end{array}$ & $\begin{array}{c}\text { Subjective Norm } \\
\text { of Green } \\
\text { Buildings (SN) }\end{array}$ & $\begin{array}{c}\text { Behavior } \\
\text { Intention }\end{array}$ \\
\hline PU & $\mathbf{0 . 7 6 1}$ & & & & & \\
\hline PEU & 0.563 & $\mathbf{0 . 7 2 6}$ & & & & \\
\hline AT & 0.642 & 0.471 & $\mathbf{0 . 7 5 6}$ & & & \\
\hline MC & 0.753 & 0.452 & 0.553 & $\mathbf{0 . 7 8 2}$ & & \\
\hline SN & 0.564 & 0.563 & 0.621 & 0.637 & $\mathbf{0 . 7 6 6}$ & $*$ \\
\hline Behavior Intention & 0.443 & 0.568 & 0.353 & 0.413 & 0.642 & $\mathbf{0 . 8 6 2}$ \\
\hline
\end{tabular}

Diagonal element (bold) are the square root average extracted (AVE) between the constructs and their measures. Off-diagonal elements are correlations between the constructs.

Table 4. Results of the overall Model Fit

\begin{tabular}{|c|c|c|c|}
\hline Fit Indices & Recommended values for good fit & Model values & Supported \\
\hline$\chi^{2}$ (Chi-square) & the smaller the better & 322.02 & \\
\hline$\chi^{2} / \mathrm{df}$ & $<3$ & 1.30 & Yes \\
\hline GFI & $>0.9$ & 0.93 & Yes \\
\hline AGFI & $>0.8$ & 0.83 & Yes \\
\hline RMSEA & $<.08$ & 0.06 & Yes \\
\hline CFI & $>0.9$ & 0.92 & Yes \\
\hline NFI & $>0.9$ & 0.91 & Yes \\
\hline NNFI & $>0.9$ & 0.96 & Yes \\
\hline RMR & $<0.08$ & 0.06 & Yes \\
\hline SRMR & $<0.08$ & 0.07 & Yes \\
\hline RFI & $>0.9$ & 0.92 & Yes \\
\hline IFI & $>0.9$ & 0.93 & Yes \\
\hline PGFI & $>0.5$ & 0.72 & Yes \\
\hline PNFI & $>0.5$ & 0.68 & Yes \\
\hline
\end{tabular}

\subsection{Structural Model and Hypotheses Testing}

According to table 3 , all of the path coefficient is larger than 0.45 , and the $P$ value is less than 0.05 . That means all the hypotheses have been supported and have significant effect. When it comes a mediator, indirect effect will be the multiplier between two path coefficients [19].

The result from this study indicated that perceived usefulness, and perceived ease of use green building restaurants in Taiwan has an indirect effect on intention through attitude; second, motivation to comply has indirect effect passes through both subjective norm and attitude sequentially, with subjective norm affecting attitude. Finally, motivation to comply has an indirect effect on intention through subjective norm.

\subsubsection{Reliability and validity analyses}

Two-step structural equation modeling was used for model testing. Maximum likelihood was used for all parameter estimation with Amos. First confirmatory factor analysis (CFA) is conducted to evaluate the model used to measure the modeled constructs. CFA enables testing of the reliability, convergent validity and discriminate validity of the measurement model. The reliability and internal validity of the measurement model is examined by calculating the composite reliability (CR) and average variance extracted (AVE).

Table 2 shows that all the constructs have acceptable composite reliability coefficients, since they exceed 0.6 . The AVE of each measure accounts for more than $50 \%$ of 
the variance, and indicates that the variance captured by the construct exceeds that due to the measurement error. Therefore, the measurement model has adequate internal validity. Convergent validity measures the correlation between two observed variables used to measure the same construct and is expected when the estimated pattern coefficient on the underlying construct factor of the estimated pattern of each coefficient is significant. Items have factor loadings exceeding 0.45 .

Table 3 exams the AVE for each of the latent constructs and comparing this with the squared correlations among the constructs revealed that the shared variance among any two constructs (that is, the square of their inter-correlation) was always less than the average variance explained by the construct, suggesting discriminate validity.

Table 3 lists the result of discriminate validity. This study concludes that all measures exhibit construct validity. Based on all of the reliability and validity analysis, the construct scale appears to exhibit satisfactory measurement qualities and is adequate.

\subsubsection{Hypotheses Testing}

The simultaneous maximum-likelihood-estimation procedures are used to examine the hypothesized relationships among total quality management, market orientation and hotel performance. Table 4 shows that the structural model exhibits a good fit with the data, with fit indices of Root Mean Square Error of Approximation (RMSEA), Goodness-of-Fit Index (GFI), Adjusted Goodness-of-Fit Index (AGFI), and Comparative Fit Index (CFI) fulfilling the respective benchmarks. Table 2 also shows the path coefficients for the model and their significance. Regarding the hypothesis tests, all of the hypothesized relationships are supported for the estimated structural model.

\section{Discussion}

Perceived usefulness of green buildings and perceived ease of use green buildings has positive effect on attitude of green buildings.

This study concluded that $\mathrm{H} 1$ and $\mathrm{H} 2$ have been supported. That means that green buildings restaurants will improve their performance, working environment, boost organization image, and relief ecology pollution through degree of employees' participation of perceived usefulness of green buildings and perceived ease of use green buildings [29].

This study also indicated that attitude of green buildings will effect applying intention (H5). That means that green buildings restaurants will enhance the degree of behavior intention if employees perceive green building conduct is sensible and meaningful. Meanwhile, employees will also persuade others to participate [37].

Subjective norm of green buildings will affect attitude (H4). Employees of green buildings restaurants care the degree of participation in recognition from colleagues, friends and relatives, etc. It will directly affect the employees' negative or positive evaluation in green building activities [48].

Subjective norm of green buildings will affect behavior intention (H6). The degree of employees' intention participation in green building will have a direct impact by colleagues, friends and relatives. When it come identity from an influential person, an employee will have more passion to participate in green building activities. No not only participate personally, but will persuade others to participation in green construction activities [42,69].

Motivation to comply of green buildings will affect subjective norm of green buildings (H3). With positive support or negative opposition, an important reference groups, such as family, friends or colleagues, will influence employees' perspective to participate green building restaurants activities [12].

There are several reasons that present why green restaurants relieve ecology threatening: first, most restaurants generally constructed with concrete, bricks, tile, steel and chemical painting materials. That plunders resources from ecology. Second, using green or recycling material to construct buildings would reduce the certain costs. According to this study, employees' contribution and perception will affect operations more environmentally friendly. In order to make restaurants go green, it is important to set up certification organization to arouse green practice perception of restaurants in Taiwan. Government policies enforce and make pressure to implement green practices, for example, recycling hazardous product waste, conserving water, or conserving energy, or using ecological constructing materials. This result would reinforce the belief and perception of restaurants owners and employees.

\section{Conclusions}

\subsection{Managerial Practices}

Restaurant managers make determination to use environmental practices as a part of the company's strategy then employee could conduct operations with environment friendly. This study may direct effect to practitioners in the hospitality sector. First, sustainability enhances value in times of global warming and ecology deteriorating. Green restaurants in Taiwan have a direct effect on firm performance through green capability, efficiency improvement and competitive improvement during economic downturn and achieve better positioning in the market. Second, restaurants managers or executives should consider adopting certain green practices to achieve cost reduction and construction. Thus, communication with employees of these green policies increases their perception of environmental sustainability is essential for restaurants.

\subsection{Conclusions}

1. If employees are satisfied with the green restaurants 
provided such as low costs [59] materials and environment friendly, then employees will have high levels of intention of applying green materials in restaurants. 2. If the green restaurants enable employees work efficiently, conveniently in the green environment then the employees' positive attitude toward applying green restaurants will increase. 3 . If the green restaurants are ease-of-using, the operation environments are user friendly; this concept will affect employees' intention toward applying green restaurants. 4 . The degree of positive and negative subjective norm of employees in applying green restaurants is the most important factor that affects whether employees' intentions will apply green restaurants. Green material helpful in reducing carbon emissions In other words, to promote actual use of green materials in the construction industry, enhancing the perceived usefulness of green materials is the most efficient method.

\section{REFERENCES}

[1] Ajzen, I. (2002). Perceived behavioral control, self-efficacy, locus of control, and the theory of planned behavior. Journal of Applied Social Psychology, 32, 1-20.

[2] Ajzen, I., Albarracin, D. \& Hornik, R. (2007). Predicting and Changing Behavior. In I. Prediction and Change of Health Behavior: Applying the Reasoned Action Approach. Lawrence Erlbaum Association, Inc., USA.

[3] Ajzen, I., \& Driver, B. L. (1991). Prediction of leisure participation from behavioral, normative, and control beliefs: an application of the theory of planned behavior. Leisure Sciences, 13, 185-204.

[4] Ajzen, I., \& Fishbein, M. (1980). Understanding attitudes and predicting social behavior. Englewood Cliffs, NJ: Prentice-Hall, USA.

[5] Ajzen, I., \& Fishbein, M. (2005). The influence of attitudes on behavior, in: D. Albarracín, B. T. Johnson \& M. P. Zanna (Eds.), Handbook of attitudes and attitude change: basic principles. Mahwah, NJ: Erlbaum, USA.

[6] Ajzen I., \& Madden, T. J. (1986). Prediction of goal-directed behavior: attitudes, intentions, and perceived behavioral control. Journal of Experimental Social Psychology, 22, $453-474$.

[7] Albarracin, D., Johnson, B. T., Fishbein, M., \& Muellerleile, P. A. (2001). Theories of reasoned action and planned behavior as models of condom Use: A meta-analysis." Psychological Bulletin, 127(1), 142-161.

[8] Albarracin, D., Kumkale, G. T., \& Johnson, B. T. (2004). Influences of social power and normative support on condom use decision: a research synthesis. AIDS Care, 6(6), 700-723.

[9] American Society of Testing and Materials (ASTM), 2009. ASTM E 2432 - 05 Standard Guide for General Principles of Sustainability Related to Buildings. West Conshohocken: PA.

[10] Armitage, C. J., \& Conner, M. (2001). Efficacy of the theory of planned behaviour: a meta-analytic review. British Journal of Social Psychology, 40(Pt 4), 471-499.
[11] Askar, P., \& Umay, A. (2001). Pre-service elementary mathematics teachers' computer self-efficacy, attitudes towards computers, and their perceptions of computer-enriched learning environments. In Proceedings of Society for Information Technology and Teacher Education International Conference, Chesapeake, VA: AACE, 2262-2263.

[12] Bagozzi, R. P., Wong N., Abe, S., \& Bergami, M. (2000). Cultural and Situational Contingencies and the Theory of Reasoned Action: Application to Fast Food Restaurant Consumption. Journal of Consumer Psychology, 9(2), 97-106

[13] Bamberg, S. \& Möser, G. (2007). Twenty years after Hines, Hungerford, and Tomera: a new meta-analysis of psycho-social Determinants of pro-environmental behaviour. Journal of Environmental Psychology, 27(1), 14-25.

[14] Bohdanowicz, P. (2005). European hoteliers' environmental attitudes: greening the business. Cornell Hospitality Quarterly, 46(2), 188-204.

[15] Boo, S., \& Park, E. (2013). An examination of green intention: The effect of environmental knowledge and educational experiences on meeting planners' implementation of green meeting practices. Journal of Sustainable Tourism, 21(8), 1129-1147.

[16] Chan, S.W. (2013). Gap analysis of green hotel marketing. International Journal of Contemporary Hospitality Management, 25(7), 1017-1048.

[17] Chan, W., \& Wong, K.(2006). Estimation of weight of solid waste: newspapers in Hong Kong hotels. Journal of Hospitality \& Tourism Research, 30 (2), 231-245.

[18] Chau, P. Y. K. (2001). Influence of computer attitude and self-efficacy on IT usage behaviour. Journal of End-User Computing, 13(1), 26-33.

[19] Chen, K.-Y. \&Wang, C.-H., (2012). Advanced statistical analysis using SPSS and AMOS, Wu-Nan Book Incorporation, Taipei, Taiwan.

[20] Chiu, J.-Z., \& Hsieh, C.-C. (2016). The impact of restaurants' green supply chain of practices on firm performance. Sustainability, 8, 42.

[21] Cordano, M., Welcomer, S., Scherer, R. F., Pradenas, L., \& Parada, V. (2011). A cross cultural assessment of three theories of pro-environmental behavior: A comparison between business students of Chile and the United States. Environment and Behavior, 43(5), 634-657

[22] Davis, F. (1989). Perceived usefulness, perceived ease of use, and user acceptance of information technology. MIS Quarterly, 13, 319-340.

[23] De Moura, A., Cunha, L., Castro - Cunha, M., \&Lima, C. (2012). A comparative evaluation of women's perceptions and importance of sustainability in fish consumption: an exploratory study among light consumers with different education levels. Manag. Environ. Qual.: Int. J., 23(4), $451-461$.

[24] Department of Industrial Works (DIW). (2013).Green Industry Manual: The Guideline for Green Industry Promotion and Development, 5th ed.; Office of the permanent secretary for ministry of industry: Bangkok, Thailand, pp. $7-13$.

[25] D’Souza, C., \& Taghian, M., (2005). Green advertising 
effects on attitude and choice of advertising themes. Asian Pacific Journal of Marketing and Logistics, 17, 51-66.

[26] Fishbein, M., \& Ajzen, I. (1975). Belief, attitude, intention, and behavior: an introduction to theory and research. Reading, MA: Addison-Wesley, USA.

[27] Fraj, E. \&Martinez, E. (2007). Ecological consumer behaviour: an empirical analysis. International Journal of Consumer Studies, 31(1), 26-33.

[28] Fusilier, M., \& Durlabhji, S. (2005). An exploration of student internet use in India. Campus-Wide Information Systems, 22(4), 233-246.

[29] Gefen, D., Karahanna, E., \& Steaub, D. W. (2003), Trust and TAM in Online Shopping: an integrated model. MIS Quarterly, 27(1), 51-90.

[30] Glanz, K., Rimer B. K., \& Viswanath, K. (2008). Health Behavior and Health Education: Theory, Research, and Practice, 4th ed., Jossey-Bass, San Francisco, CA, USA.

[31] Han, H. (2014). The norm activation model and theory-broadening: Individuals' decision-making on environmentally-responsible convention attendance. Journal of Environmental Psychology 40, 462-471.

[32] Han, H. (2015). Travelers' pro-environmental behavior in a green lodging context: converging value-belief-norm theory and the theory of planned behavior. Tourism Management, 47, 164-177.

[33] Han, H., Hsu, L., \& Sheu, C. (2011). Application of the theory of planned behavior to green hotel choice: Testing the effect of environmental friendly activities. Tour. Manag., 31, $325-334$.

[34] Han, H., \& Kim,Y.(2010). An investigation of green hotel customers' decision formation: Developing an extended model of the theory of planned behavior. International Journal of Hospitality Management, 29, 659-668.

[35] Hansla, A., Gamble, A., Juliusson, A., \& Gärling, T.(2008). Psychological determinants of attitude towards and willingness to pay for green electricity. Energy Policy, 36(2), 768-774.

[36] Hsieh, Y.-C. (2012), Hotel companies= environmental policies and practices: a content analysis of their web pages. International Journal of Contemporary Hospitality Management, 24 (1), 97-121.

[37] Hsu L.L., Hsu T. H. \& Wu S. J. (2009). The antecedents of influencing usage intention in blog context. International Journal of Information Management, 19(1), 63-74.

[38] Hu, H.-H., Parsa, H.G., \& Self, J., (2010). The dynamics of green restaurant patronage. Cornell Hospitality Quarterly, 51, 344-362.

[39] Hu, P. J., Clark, T. H. K., \& Ma, W. W. (2003). Examining technology acceptance by school teachers: A longitudinal study. Information \& Management, 41(2), 227-241.

[40] Huang, C.-Fah., \& Chen, J.-L., (2015). The promotion strategy of green construction materials: a path analysis approach. Materials, 6999-7005.

[41] Huang, H. M., \& Liaw, S. S. (2005). Exploring user's attitudes and intentions toward the web as a survey tool. Computers in
Human Behavior, 21(5), 729-743.

[42] Huang, H.-T., Tsai, C.-H., \& Zhu, D.-S. (2009). An extension of the motivation model to explore the behavioral intention of health knowledge repository systems: Technological-Social-Motivational Perspectives. Journal of e- Business, 11(3), 569-610.

[43] Jones, P., Hillier, D. \& Comfort, D. (2014). Sustainability in the global hotel industry. International Journal of Contemporary Hospitality Management, 26(1), 5-17.

[44] Justin P., Ashwin M., \& Jayesh, P. (2016). Predicting green product consumption using theory of planned behavior and reasoned action. Journal of Retailing and Consumer Services, $29,123-134$.

[45] Kang, S. \& Hur, W.H. (2012). Investigating the antecedents of green brand equity: a sustainable development perspective. Corporate Social Responsibility and Environmental Management, 19(5), 306-316.

[46] Klöckner, C. A. (2013). A comprehensive model of the psychology of environmental behavior-A meta-analysis. Global Environmental Change, 23, 1028-1038.

[47] Kubba, S., (2010). Green construction Project Management and Cost Oversight. Elsevier, U.S.A.

[48] Kuo, C.- J., Hou, J.-S., Kuo, J.-K., Ou, S.-P., \& Hsieh C.-H. (2009). An examination of the theory of planned behavior for community practices in a landscape renaissance project. Journal of Architecture, 69, 137-154.

[49] Lin, S.-C., Persada, S, F., Nadlifatin, R., Tsai, H.-Y., \& Chu, C.-H. (2015). Exploring the influential factors of manufacturers' initial intention in applying for the green mark EcoLabel in Taiwan. International Journal of Precision Engineering and Manufacturing- Green Technology, 2(4), 359-364.

[50] Lin, S-C., Tsai, H-Y., \& Shen, T-Y. (2014). An Investigation on the influential factors of green product manufacturers' experiences and decisions to apply for eco-label "Green Mark" in Taiwan. Proc. of the International Conference on Service Sciences and Innovation.

[51] Liu, X., Yang, J., Qu, S., Wang, L., \& Shishime, T. (2012). Sustainable production: practices and determinant factors of green supply chain management of Chinese companies. Business Strategy and the Environment, 21(1), 1-16.

[52] Lorenzini, B. (1994). The green restaurant, part II: Systems and service. Restaur. Inst., 104, 119-136.

[53] Manaktola, K., \& Jauhari, V. (2007). Exploring consumer attitude and behavior towards green practices in the lodging industry in India. International Journal of Contemporary Hospitality Management, 19 (5), 364-377.

[54] Matthies, E., Selge, S., \& Klöckner, C. A. (2012). The role of parental behavior for the development of behavior specific environmental norms: The example of recycling and re-use behavior. Journal of Environmental Psychology, 32, 277-284.

[55] Menikpura, S.N.M., Sang-Arun, J., \& Bengtsson, M. (2016). Assessment of environmental and economic performance of waste-to-energy facilities in Thai cities. Renew Energy, 86, $576-584$.

[56] Montaño, D. E.\& Kasprzyk, D. (2008).Theory of Reasoned 
Action, Theory of Planned Behavior, and the Integrated Behavioral Model, Jossey-Bass, San Francisco, CA, USA.

[57] Myers, J. M., \& Halpin, R. (2002) Teachers' attitudes and use of multimedia technology in the classroom: constructivist-based professional development training for school districts. Journal of Computing in Teacher Education, 18(4), 133-140.

[58] Onwezen, M. C., Antonides, G., \& Bartels, J. (2013). The norm activation model: an exploration of the functions of anticipated pride and guilt in pro-environmental behavior. Journal of Economic Psychology, 39, 141-153.

[59] Rust, R.T., Moorman, C., \& Dickson, P.R. (2002).Getting return on quality: revenue expansion, cost reduction, or both? J. Market, 66, 7-24.

[60] St. Lawrence, J. S., \& Fortenberry, J. D. (2007). Behavioral Interventions for STDs: Theoretical Models and Intervention Methods. In S. O. Aral and J. M. Douglas (eds.), Behavioral Interventions for Prevention and Control of Sexually Transmitted Diseases, Springer, New York, USA.

[61] Szajna, B. (1996). Empirical evaluation of the revised technology acceptance model. Manag. Sci., 14, 85-92.

[62] Teo, T. (2006) Attitudes toward computers: A study of post-secondary students in Singapore. Interactive Learning Environments, 14(1), 17-24.

[63] U.S. Green Building Council. (2013), LEED Reference Guide for Interior Design and Construction, U.S. Green Building Council, United States: Washington, DC., USA.

[64] Venkatesh, V., \& Davis, F. D., (2000). A theoretical extension of the technology Acceptance Model: Four Longitudinal Field Studies, Management Science, 46(2), 186-204.

[65] Webb, T. L., \& Sheeran, P. (2006). Does Changing Behavioral Intentions Engender Behavior Change? A meta-analysis of the experimental evidence. Psychological Bulletin, 132, 249-268.
[66] Whitfield, J., Dioko, L. A. N., \& Webber, D. E. (2014). Scoring environmental credentials: A review of UK conference and meetings venues using the greener venue framework. Journal of Sustainable Tourism, 22(2), 299-318.

[67] Wiengarten, F.\& Pagell, M.(2012). The importance of quality management for the success of environmental management initiatives. International Journal of Production Economics, $140,407-415$.

[68] Woodrow, J. E. J. (1991). A comparison of four computer attitude scales. Journal of Educational Computing Research, $7(2), 165-187$.

[69] Yigitcanlar, T., Dur, F., \& Dizdaroglu, D. (2015).Towards prosperous sustainable cities: a multiscalar urban sustainability assessment approach. Habitat Int., 45, 36-46.

[70] Yousafzai, S. Y., Foxall, G. R., \& Pallister, J. (2007a). Technology acceptance: A meta-analysis of the TAM. Part 1. Journal of Modelling in Management, 2, 251-280.

[71] Yousafzai, S. Y., Foxall, G. R., \& Pallister, J. (2007b). Technology acceptance: A meta-analysis of the TAM. Part 2. Journal of Modelling in Management, 2, 281-304.

[72] Yousafzai, S.Y., Foxall, G. R. \& Pallister, J. G. (2010). Explaining internet banking behavior: theory of reasoned action, theory of planned behavior, or technology acceptance model? Journal of Applied Social Psychology, 40, 5, 1172-1202.

[73] Zhang, Y., Wang, Z., \& Zhou, G. (2013). Antecedents of employee electricity saving behavior in organizations: An empirical study based on norm activation model. Energy Policy, 62, 1120-1127.

[74] Available online: http://www.construction-chemicals.com/ pr oduct/construction-chemicals/Documents/drymix-conference -yearbook-2007.pdf (accessed on 8 October 2015).

[75] Online Available: http://www.environmentallyfriendlyhotels.com (June 10, 2009). 